\title{
Infância e Sociedade em A casa da madrinha, de Lygia Bojunga Nunes
}

\section{Childhood and Society: A casa da madrinha, Lygia Bojunga Nunes.}

Carlos Pires é Mestre e Doutorando em Letras pela Universidade de São Paulo e professor do Instituto Superior de Ensino Vera Cruz (ISE Vera Cruz) nos cursos "Formação de escritores" e "Alfabetização".

\section{Contato: pirescarlos@gmail.com}

Ana Lúcia Madsen Gomboeff é pós-graduada em Análise do Discurso pela Pontifícia Universidade Católica de São Paulo (PUC-SP) e especialista em Alfabetização pelo ISE Vera Cruz, onde realizou uma monografia sobre "A casa da madrinha" de Lygia Bojunga Nunes. Atualmente trabalha como coordenadora pedagógica na prefeitura de São Paulo.

\section{Contato: ana.madsen@ig.com.br}

Lygia Bojunga está entre os mais destacados escritores do mundo para crianças e jovens. Como se sabe, ela recebeu o Hans Christian Andersen, principal prêmio de literatura infanto-juvenil. A bolsa amarela, de 1976, é um marco em sua obra, momento em que ela consegue estabelecer a sofisticada voz narrativa de uma menina em crise, ao mesmo tempo, com sua família, com seus desejos e com sua imaginação. A famosa Raquel, personagem e narradora do livro, está situada entre um mundo que se perspectiva de sua imaginação e outro real, ou da realidade de uma menina de classe média baixa com muitos irmãos e pouco espaço. Esse conflito entre sua imaginação - que ela acaba arranjando dentro da bolsa amarela - e a realidade acaba por gerar uma bonita trama que leva à transformação da personagem. A menina aprende a conviver com seus desejos e com sua imaginação de maneira mais integrada ao real; em outras palavras, Raquel cresce 
efetivamente ao preço de redimensionar realidade e fantasia, não sem certa melancolia mesclada de esperança.

A casa da madrinha, de 1978, é o livro que segue $A$ bolsa amarela. A autora procurou ampliar o quadro social no qual acontece a história, colocando em seu centro Alexandre, um menino pobre, morador de uma favela no Rio de Janeiro. Ele abandonou a família à procura da casa de sua madrinha, lugar inventado por seu irmão para distrair Alexandre em momentos de fome ou falta de sono. Ao que parece, Bojunga encontrou certa dificuldade na construção dessa voz narrativa, a ponto de recolocar um narrador mais tradicional do que o de seu livro anterior.

Com a criação de Alexandre, a autora tenta responder a um contexto bem demarcado na época. Segundo Marisa Lajolo e Regina Zilberman, "[na literatura infantil,] a crítica mais radical da sociedade brasileira contemporânea, tematizada através da miséria e do sofrimento infantil, vai desde então se encorpando progressivamente. E se exprime em uma representação realista do contexto social, a partir de 1977" (Lajolo e Zilberman,1985:126), o que desloca a prática de privilegiar apenas situações não problemáticas nos livros infantis. A resposta que a autora procura oferecer a esse contexto dificulta a inclusão na organização literária de um ponto de vista que dê conta de considerar a maneira específica com que a criança enxerga a realidade, como no caso de Raquel. No entanto, soluções são pensadas durante a constituição da narrativa a fim de se estabelecer um ponto de vista próximo ou aproximado ao da criança, mesmo que este apareça enquadrado por um narrador.

A indeterminação entre realidade e fantasia, que já era um problema central em $A$ bolsa amarela, aparece vinculada a uma dimensão social e cotidiana marcada, principalmente, por Alexandre e por um pavão que fala. A ampliação desse quadro social força todo um reequilíbrio dos elementos fantasiosos. A própria casa da madrinha vai-se revelando como uma espécie de mito que resolveria todos os desejos e todas as carências do garoto pobre, até o momento em que ela se materializa em uma espécie de delírio coletivo dos personagens.

Esses recuos ou rearranjos em relação ao livro A bolsa amarela aparecem também na construção espacial. A história não mais acontece em um ambiente urbano, mas a meio caminho entre a realidade rural - o que remete a uma construção tradicional na literatura para crianças no Brasil desde O Sítio do Picapau Amarelo, de Monteiro Lobato - e a urbana - que aparece, principalmente, 
por meio das recordações dos personagens. Vera, a filha de um sitiante que se torna uma importante interlocutora de Alexandre, fornece um ponto de vista que parece oscilar entre o mundo dos adultos e os delírios do personagem principal. 0 narrador realiza rápidas atribuições das vozes e passa a orquestrar esses diálogos, os quais, em diversos momentos, ganham autonomia.

A configuração ainda que simbólica de A casa da madrinha é fruto de um projeto que, além de discutir a representação da criança na família e na sociedade, perspectiva alguns ideais sociais. A casa representa um espaço mítico que faz a ponte entre fantasia e realidade, fato que situa o leitor em um contexto, ao mesmo tempo, real, histórico - devido à necessidade material e mítico - por apontar para a resolução de todos os males e de todas as dificuldades. 0 ápice da obra encontra-se no delírio final que envolve o leitor, em seu apelo metafórico e simbólico, bem como no exagero sensorial da cena. Todavia, a autora parece não dar conta de uma carga extremamente complexa, ou ao menos não como em seu livro anterior. Diferentemente de Raquel em A bolsa amarela, personagem que cresce, Alexandre, apesar de aparentemente fortalecido, continua procurando a casa de sua madrinha sem resolver sua questão material, ou resolvendo-a no plano da imaginação, enquanto Vera retorna ao lar sem indícios de transformação signnificativa. Essa dificuldade final revela tanto uma escritora sofisticada que sente os impasses no próprio material social que mobiliza e revela, quanto uma elaboração artística que contém uma ideia complexa de infância.

\section{REFERÊNCIAS}

BOJUNGA, Lygia. A bolsa amarela. Rio de Janeiro: Casa Lygia Bojunga, 2003.

A casa da madrinha. Rio de Janeiro: Casa Lygia

Bojunga, 2011.

LAJOLO, M. e ZILBERMAN, R. Literatura Infantil Brasileira: História \& Histórias. São Paulo: Editora Ática, 1985. 